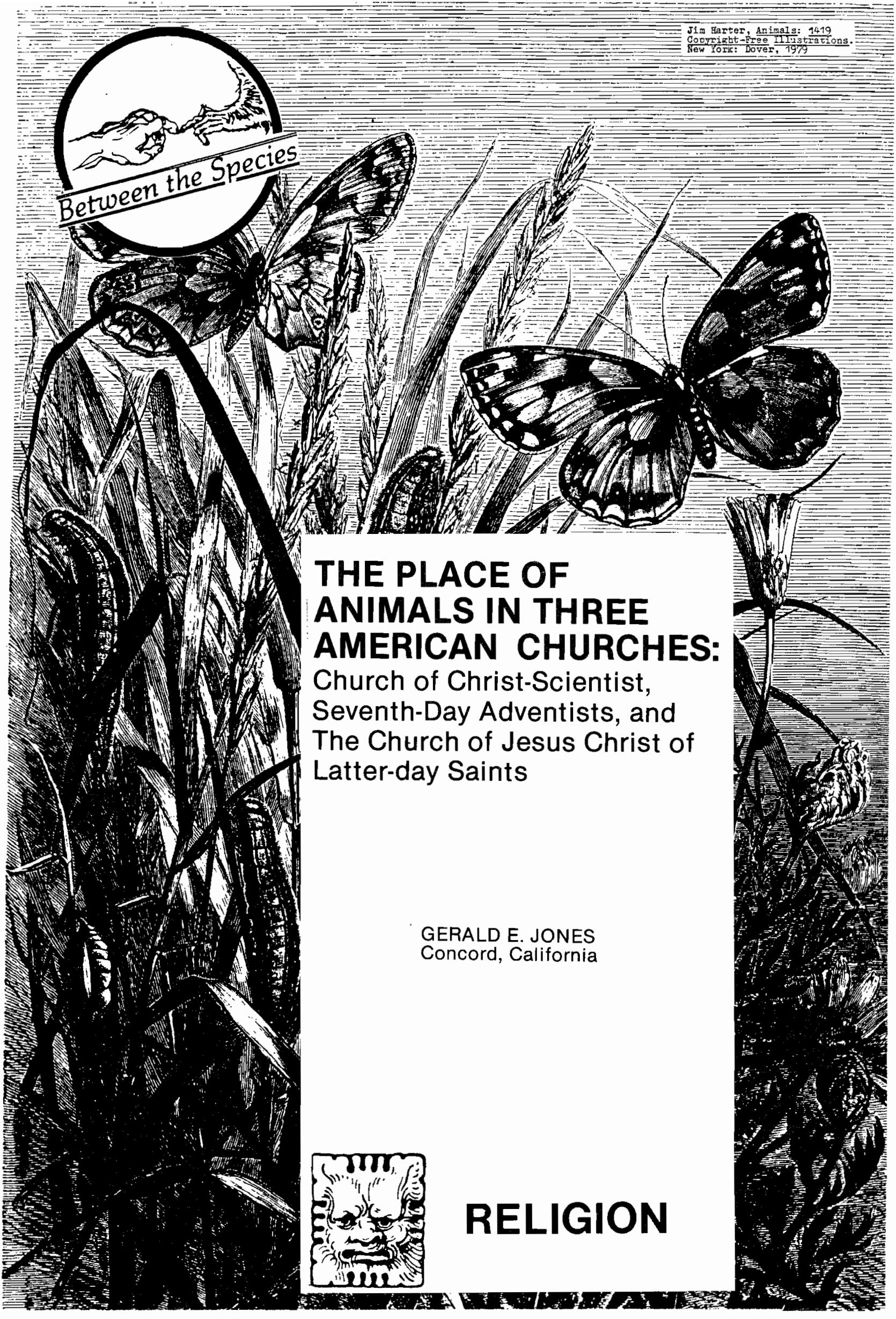


Zoophily in the Judeo-Christian culture has usually manifested itself in the form of organizations that are not oriented to organized religion. Four basic concepts have contributed to the Western reverence for the life of animals among the secular organizations sponsoring zoophilic ideals. While these four concepts are religious in nature, they are not found in the formal creeds of the larger Christian denominations of European origin.

The major rationale prompting kindness to animals is the evolutionary concept of humans and animals belonging to one large family.[1] A second principle is the promise that kindness practiced to animals will result in greater kindness to humankind. [2] Vegetarianism has been a third motivating factor in the practice of zoophily. Even though vegetarianism may be practiced strictly for the benefit of human health, it has resulted in a sparing of animal life.[3] Finally, there is the rarer concept that animals will have a place in a life hereafter, and humans will be held accountable by God for their treatment of these eternal creatures. [4]

Most Christian denominations have not supported zoophily, although few have been opposed to it. Silence has been the general rule. Many have felt that there are too many important questions concerning humans to become interested in animals.[5] Although some Catholics and fundamentalist Christians have denounced concern for animals, three churches originating in America in the nineteenth century have made more positive statements concerning animals. These are the Christian Scientists, Seventh-Day Adventists, and the Church of Jesus Christ of Latter-Day Saints (Mormons).

\section{Church of Christ-Scientist}

Though the Church of Christ-Scientist. has an unorthodox view of humanity and matter, its resultant view of animals has been similar to the majority of Christians. In the Christian Science view, God is "Divine Mind" and is the "conceiver of all in the universe." Matter is an illusion subject to decay and dissolution. The ultimate reality is "spirit" or "mind," and the physical matter of things or beings is illusory and temporary. Only humans have life that is an expression of "eternal Mind, which is God." Pantheism, however, is denied. Christian Science contends that the expression of life is not in strictly material bodies but in those with a "mind." Whether this type of existence extends to the animal world is somewhat vague in the literature. If animals do have minds, it is only the expression of the Divine Mind, since "sin is the belief in the real existence of a mind or minds other than the Divine Mind."[6]

Mary Baker Eddy, the founder or "discoverer" of Christian Science, has been the accepted authority and "revelator of truth to this age." Mrs. Eddy's conments concerning animals have been sparse and somewhat ambiguous. Writing in Unity of Good, she taught God's life and "spiritual good are not in these kingdoms."[7] However, Mrs. Eddy also wrote, "beasts, as well as men, express Mind . . . but they manifest less of mind." Her explanation was that the cause of all existence, as perceived by humanity, was the eternal Mind, God. In the Platonic tradition, beasts are lower and further removed from God and have less spiritual aspects of mind. In their appetites, passions, and other characteristics, they express qualities, but these are expressions more of mortal mind than of immortal mind.[8] Though the "individuality and identity of animals" is preserved by God-intelligence, Mrs. Eddy warned that one should not suppose He/She possessed life and mind. The time will come, she predicted, when the spirit will "destroy forever all belief in intelligent matter," which seemingly included animals.[9]

Vegetarianism was rejected by the founder of Christian Science, who repeated the doctrine that it was false to believe life and intelligence are in matter. Mrs. Eddy recalled a young man who had adopted a vegetarian diet to cure dyspepsia. The young man was cured when he realized the Christian Sci-

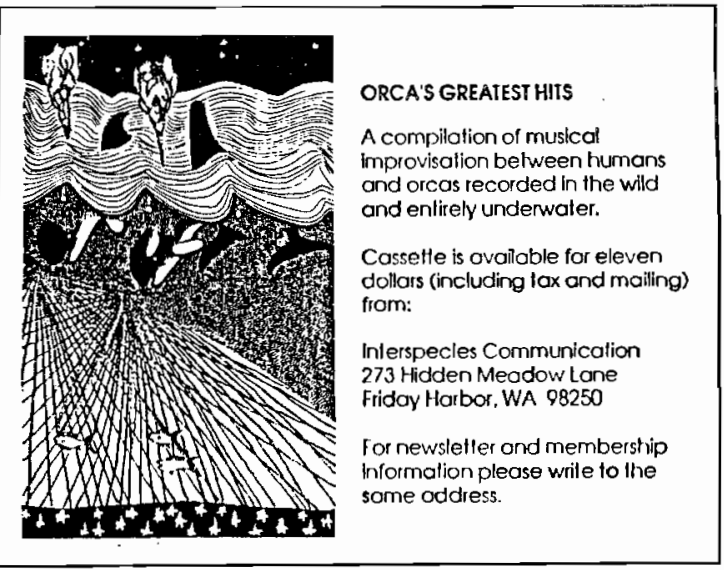


ence truth that a "bit of animal flesh" was overpowering him and his mind did not have dominion over matter. Mrs. Eddy counseled her followers not to consult the stomach about what to eat but eat what is set before one, "asking no question for conscience sake." The eating of meat was not to be rejected for either health or zoophilic reasons. [10]

Mrs. Eddy did make one zoophilic statement, however, showing more concern for animal life than had been demonstrated in her writings generally. The impression has been that humans' concern for God and an attempt to realize more fully eternal mind left little room for concern for more materialistic creatures such as animals. Nevertheless, the principle of tenderness is imparted by Spirit and thus can be evident in humanity's relationship with animals. Daniel and Paul were able to avoid harm from animals as the result of control which Love manifested over the lions and viper.[11] Climaxing this thought, Mrs. Eddy stated: "The individuality created by God is not carnivorous, as witness the millenial estate pictured by Isaiah." Though the prophetess quotes the account of peace in the animal kingdom in Isaiah 11:6, this rare zoophilic expression was not given further explanation by the developer of Christian Science, and zoophily has not been developed by later practitioners of that faith.[12]

In spite of radically unorthodox theolo9y, Christian Science has presented the same generally accepted Catholic-Protestant attitude toward animals and their treatment. All creation is from God, with humanity at the pinnacle in a descending order of created beings and things. Love expressed to its fullest should be shown to all of God's creation, but not in equal order of intensity. Animals are definitely of a lower order than humans, and humans should have dominion over the beasts. Since matter is illusory for Christian Scientists, no human nor animal will have a resurrected body of physical matter. Animal status in the life after death is not spelled out in Christian Science, but the implications are that there are no animals with minds enabling them to return to God-Mind.[13] Still unresolved in Christian Science theology is the admonition not to avoid eating flesh of animals and the conflicting dictum that individuals were not created carnivorous by God nor are they to be carnivorous in the future. It is on this stand that the Church of Christ-Scientist is in accordance with traditional Christianity. There is recognition that God has spoken concerning animals; animals have a lower rank among living beings than humans; and animals are to be used and dominated by humanity. Also taught is the principle of love which can be extended to creatures such as animals. However, in light of the cormonly recognized status of animals and the principle of loving kindness, there has been no theological justification developed for zoophily in Christian science nor for Christianity in general.

\section{Seventh-Day Adventists}

The Seventh-Day Adventists, recognizing Ellen G. White as their founder and prophetess, advocate vegetarianism. The Church was formally named in 1860 in Battle Creek, Michigan. Mrs. White's motivation towards vegetarianism seems to have been entirely health oriented. With her husband, Jarnes, she visited many health resorts and talked to many doctors, learning about proper diet to iriprove the health of herself and her husband. As a result, she came in contact with a sanitarium operated by William Kellogg in Battle creek. The famous breakfast cereals developed by Kellogg and post were advocated by the Seventh-Day Adventists.[14] Another influence on the Whites was Joseph Bates, a sailor convert to Adventisn who early in life had espoused the vegetarian diet. [15]

The medical aspect of vegetarianism has had strong advocates in this medically oriented Church throughout its history. In listing nine reasons for practising vegetarianism, one author gives only one with a zoophilic concept, when he states that the "original diet intended for man contained no flesh food."[16]

Though Ellen G. White herself stressed the health aspects of a meatless diet, she did comment upon zoophily. She wrote that it was contrary to God's plan "to have the life of any creature taken." There was no death in Eden, and indeed, God did not give humans permission to eat flesh until after the flood. Allowing humans to eat flesh was what shortened the lives of earlier humans, according to Mrs. White.[17] Probably the most representative of Seventh-Day Adventist beliefs concerning animals is the following statement by Mrs. White: 
Is it not time that all should aim to dispense with flesh food? How can those who are seeking to become pure, refined, and holy, that they may have the companionship of heavenly angels, continue to use as food anything that has so harmful an effect on soul and body? How can they take the life of God's creatures that they may consume the flesh of luxury? Let them, rather, return to the wholesome and delicious food given to man in the beginning, and themselves practice, and teach their children to practice, mercy toward the dumb creatures that God has made and placed under our dominion. [18]

More rarely does the founder stress the zoophilic aspects as she did when she suggested

Think of the cruelty to animals that meat eating involves, and its effect on those who inflict and those who behold it. How it destroys the tenderness with which we should regard these creatures of God.[19]

The only other reference to zoophily by Ellen $G$. White is her commentary upon Numbers 22:

Balaam had given evidence of the spirit that controlled him by his treatment of his beast. "A righteous man regardeth the life of his beasts: but the tender mercies of the wicked are cruel." (Proverbs 13:10) Few realize as they should the sinfulness of abusing animals or leaving them to suffer from neglect. He who created man made the lower animals also, and "His tender mercies are over all His works." (Psalms 145:9) The animals were created to serve man, but he has no right to cause them pain by harsh treatment or cruel exaction.

It is because of man's sin that "the whole creation groaneth, and travaileth in pain together." (Romans 8:22) Suffering and death were thus entailed, not only upon the human race, but upon the animals. Surely, then, it becomes man to seek to lighten, instead of increasing, the weight of suffering which his transgression has brought upon God's creatures. He who will abuse aninals because he has them in his power is both a coward and a tyrant. A disposition to cause pain, whether to our fellow men or to the brute creation, is satanic. Men do not realize that their cruelty will ever be known, because the poor dumb animals cannot reveal it. But could the eyes of these men be opened, as were those of Balaam, they would see an angel of God standing as a witness, to testify against them in the courts above. A record goes up to heaven, and a day is coming when judgment will be pronounced against those who abuse God's creatures. [20]

Mrs. White seemed to advocate zoophily for four reasons:

1. Humans should not be cruel to creatures God created and to which He shows mercy:

2. By Adam's fall, humans caused the original suffering for animals; therefore, they should be responsible for lessening their sufferings;

\section{Cruelty is satanic; and}

4. Hurnans will be judged in the hereafter for their treatment of animals.

Seventh-Day Adventism thus has had strong zoophilic tendencies, as stated by its founder. Zoophily is still not the dominant basis for their vegetarian diet, however, as stated in an official explanation of their practice: "to us, the whole matter of unclean foods is primarily a question of health. . . Our health teaching is not a matter of religious taboos."[21] Though no official support for zoophily has come from the followers of Ellen $G$. White, individual members have supported it. [22]

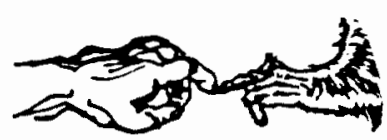




\section{The Church of Jesus Christ of Latter-day Saints}

The first reference to animal life in Latter-Day saint (Mormon) scripture is in their Doctrine and Covenants. In March, 1831, it was revealed to Joseph Smith that though vegetarianism was not to be enforced as a doctrine for humankind, humans were still responsible for their killing of animals:

And whoso forbideth to abstain from meats, that man should not eat the same, is not ordained of God:

For, behold the beasts of the field and the fowls of the air, and that which cometh of the earth, is ordained for the use of man for food and for raiment, and that he might have in abundance.

And woe be unto man that sheddeth blood or that wasteth flesh and hath no need. [23]

While revising the Bible, Joseph Smith desired further understanding concerning the four beasts mentioned in Revelation $4: 6$. Section 77 of the Doctrine and Covenants contains the response from the Lord. The answer reveals that "Heaven, the paradise of God," contains beasts, creeping things, and fowls of the air, and "every other creature which God has created." (Vs. 2)

The exact status of animals in the resurrected state is unknown except as revealed in verse four, where they are credited with being "full of knowledge" and having "power to move, to act, etc."

During the Zion's Camp expedition in the sumuner of 1834, an incident occurred that allowed a practical application of concern for animal life. As related by Joseph Smith in his history,

In pitching my tent we found three massasaugas or prairie rattlesnakes, which the brethren were about to kill, but I said, "Let them alone--don't hurt them! How will the serpent ever lose his venom, while the servants of God possess the same disposition and continue to make war upon it? Men must become harmless, before the brute creation; and when men lose their vicious dispositions and cease to destroy the animal race, the lion and the lamb can dwell together, and the sucking child can play with the serpent in safety." The brethren took the serpents carefully on sticks and carried thern across the creek. I exhorted the brethren not to kill a serpent, bird, or an animal of any kind during our journey unless it became necessary in order to preserve ourselves from hunger. [24]

That the brethren implemented the Prophet's teachings is indicated in two events that occurred about a month later on the trip:

\begin{abstract}
As Hyrum Stratton and his companion were taking up their blankets this morning, they discovered two prairie rattlesnakes quietly sleeping under them, which they carefully carried out of carnp.
\end{abstract}

And again,

While the brethren were making their beds in Captain Brigham Young's tent, one of them discovered a very musical rattlesnake which they were about to kill. Captain Young told them not to hurt him but carry him out of the tent, whereupon Brother Carpenter took him in his hands, carried him beyond all danger, and left him to enjoy his liberty, telling him not to return. [25]

Further explaining John's vision in the book of Revelations and the place of animals in the afterlife, the Prophet Joseph Smith explained that John probably saw beings in heaven of a "thousand forms" that were "strange beasts of which we have no conception." and all animals "might be seen in heaven." He also stated: "John learned that God glorified Himself by saving all that His hands had made, whether beasts, fowls, fishes, or men. "[26] animals:

He further taught the resurrection of

Says one, "I cannot believe in the salvation of beasts." Any man who would tell you this could not be, 
would tell you that the revelations are not true. John heard the words of the beast giving glory to God, and understood them. God who made the beasts could understand every language spoken by them. The beasts were four of the most noble animals that filled the measure of their creation, and had been saved from other worlds, because they were perfect. They were like angels in their sphere. We are not told where they came from, and I do not know; but they were seen and heard by John praising and glorifying God.[27]

Brigham Young also showed concern for animals. For example, in a sermon preached in Salt Lake City's old Tabernacle, he said:

"Iet the people be holy, and the earth under their feet will be holy. Let the people be holy, and filled with the Spirit of God, and every animal and creeping thing will be filled with peace. . . . The more purity that exists, the less is the strife; the more kind we are to our animals, the more will peace increase, and the savage nature of the brute creation will vanish away.[28]

President Young also warned that the Latter-Day Saints would "never inherit the Celestial Kingdon" until they learned to take proper care of the things on this earth entrusted to them by the Iord. Specifically referring to livestock, he said that the people should "take care of their cattle and horses" and the man who did not do it would "lay himself liable to censure in the eyes of justice."[29]

George Q. Cannon, a counselor in the First Presidency under Brigham Young, probably wrote more concerning the humane treatment of animals than any other Latter-Day Saint. As editor of the Juvenile Instructor, the magazine for the Sunday School organization of the Mormon Church, he began in 1868 writing editorials advocating kindness to animals. In 1907 he announced the inauguration of the Sunday School-sponsored Humane Day, to be commemorated during the month of February. This program continued in the Church for the next twenty years.

Although the Sunday School has not spon- sored any official humane programs since 1918, there were articles concerning zoophily in the Instructor magazine with titles such as "Do You Treat Your Pets with Kindness?,"[30] "Reverence for Life,"[31] and "Thou Shalt Not Kill."[32] That last article refers to hunting.

The Primary organization, for children under the age of twelve, began to stress humane treatment of animals in 1902, with the first issue of their magazine, The Children's Friend. Then, in its January, 1952, issue, the Primary organization began its sponsorship of the "Kindness to Animals Club" and invited Primary children to join. on page twenty-two, the top half of the page encouraged all children to join, with the headline "Kindness to Animals Club. A brand new club for all boys and girls. Will you be an active, livewire member?" The invitation continued by stating: "There are all kinds of clubs, but what could be more fun than to share in doing good and being kind to all animal life?" The creed consisted of three promises to be signed by the applicant:

\section{I will feed my pets and take care of them as I should.}

\section{I will be kind to all animal life.}

3. I will try to get others to do the same. [33]

The last invitation to join the "Kindness to Animals Club" was in the December, 1956, issue of The Children's Friend, ending the seoond major zoophilic program sponsored by a Iatter-Day Saints Church auxiliary.

Lorenzo Snow served as President of the L.D.S. Church from 1898 to 1901. He was an avid hunter in his youth, but he recalls that at the age of twenty-four, a strong feeling came over him that killing animal life was sinful. He attributed this change in attitude to the teachings of Joseph Smith. He recorded in his journal:

While moving slowly forwand in pursuit of something to kill, my mind was arrested with the reflection on the nature of my pursuit-that of amusing myself by giving pain and death to harmless, innocent creatures that perhaps had as much right to life and enjoyment as 
myself. I realized that such indulgence was without any justification, and feeling condemed, I laid Iny gun on my shoulder, returned home, and from that time to this have felt no inclination for that murderous amusement. [34]

During the twentieth century, all of the presidents of the Mormon Church have made statements that relate to zoophily, except for Harold $B$. Lee, who served as president less than two years. Heber J. Grant and George Albert Smith did not refer directly to the treatment of animals but, rather, to the concept of meat in their diet. In General Conference, Heber J. Grant stated:

I think that another reason why I have very splendid strength for an old man is that during the years we have had a cafeteria in the Utah Hotel I have not, with the exception of not more than a dozen times, oxdered meat of any kind. on those special occasions I have mentioned, I have perhaps had a small, tender lamb chop. I have endeavored to live the word of Wisdam, and that in my opinion, is the one reason for my good health. [35]

George Albert Smith's son-in-law, Robert Murray Stewart, made some comments on the President's food preferences. This report, published during President Snith's lifetime, stated: "In the summer he eats no meat, and even in the winter months, he eats very little." [36]

Other twentieth century Presidents of the L.D.S. Church who have spoken out frequently on behalf of zoophily are Joseph $F$. Smith and David O. McKay. Both President Smith and President Mckay were superintendents of the General Sunday School and were co-editors of the Jurvenile Instructor when they sponsored Humane Day. In February, 1912, President Snith wrote a two-page editorial entitled "Kindness to Animals?" Here is a sample of it:

Kindness to the whole animal creation and especially to all domestic animals is not only a virtue that should be developed, but is the absolute duty of mankind. . . . It is an unrighteous thing to treat any creature cruelly. . . . It will be a blessed day when mankind shall accept and abide by the Christ-like sentiment expressed by one of the poets in the following words: "Take not away the life you cannot give, For all things have an equal right to live."[37]

An editorial published in the Juvenile Instructor in April, 1918, was considered of such significance that it was repeated in April, 1927. It stated:

What is it to be humane to the beasts of the fields and birds of the air? It is more than to be considerate of the animal life entrusted to our care. It is a grateful appreciation of God's creations. It is the lesson of divine love. To Him all life is a sacred creation for the use of $\mathrm{His}$ children. Do we stand beside Him in our tender regard for life?

Our sense of appreciation should be quickened by a desire to understand divine purposes, and to keep the balance of animal life adjusted to the needs of creation. Man in his wanton disregard of a sacred duty has been reckless of life. he has destroyed it with an indiffer: ence to the evil results it would entail upon the earth. Birds have been uselessly slaughtered, and pests have sprung up as a consequence to plague the people of the world. Animals in the providence of the creation have been intended as a prey upon one another. They preserve a safe balance for the benefit of man.

- - The unnecessary destruction of life is a distinct spiritual: loss to the human family. Men: cannot worship the creator and look with careless indifference upon $\mathrm{His}$ creations. The love of all life' helps man to the enjoyment of $a$ better life. It exalts the spiritual nature of those in need of divine favor.

The wanton destruction of life reacts upon the humar family. There is something in the law of 
compensation which makes criminals injure and destroy life. Men who are unsympathetic toward the life of domestic animals entrusted to them usually receive the reward of their cruelty by the dumb animals which they mistreat. Love begets love in all creation, and nature responds bounteously to the tender treatment of man.

- . Nature helps us to see and understand God. To all His creations we owe an allegiance of service and a profound admiration. Man should be kind to the animals which serve him both directly and indirectly. An angry word or a brutal blow wounds the heart from which it comes. Love of nature is akin to the love of cod; the two are inseparable. [38]

President David O. McKay in General Conference remarked that: "A true Latter-Day Saint is kind to animals, is kind to every created thing, for God has created all." [39] Six months later, in the Annual Conference, he commended the previously mentioned Kindness to Animals Club:

Another very commendable feature is the Kindness to Animals club being sponsored by The Children's Friend. I commend to your attention, especially when we sense the reports that we have had recently regarding some sadist boys who have been going around with 22's shooting, just for the mere sport, the starving deer. [40]

In 1942, Joseph Fielding Smith gave a series of lectures on Church doctrine. In one of these evening talks in the Assembly Hall (on Temple Square in Salt Lake City), he said:

What did Isaiah say? Before you get through asking, I will answer. The lion, as well as the lamb, these animals that now are so filled with vicious habits will then be at peace, and so it says here there will be no enmity between man and beast, and we will not to go off and kill deer when that time comes. [41]

In a Melchizedek Priesthood manual for
1947, President Smith declared:

It is a grievous sin in the sight of God to kill merely for sport. such a thing shows a weakness in the spiritual character of the individual. We cannot restore life when it is taken, and all creatures have a right to enjoy life and happiness on the earth where the Lord has placed them. only for food, and then sparingly, should flesh be eaten, for all life is from God and is eternal. [42]

Answering a question in the Improvenent Fra, an official Church magazine, on the sinfulness of killing animals wantonly, President Smith stated:

There is no inference in the scriptures that it is the privilege of man to slay birds or beasts or to catch fish wantonly. The Lord gave Iife to every creature, both the birds in the heavens, beasts on earth, and the fishes in the streams or seas. They also were commanded to be fruitful and multiply and fill the earth. It was intended that all creatures should be happy in their several elements. Therefore to take the life of those creatures wantonly is a sin before the Lord.

It is easy to destroy life, but who can restore it when it is taken? Moreover, were not all creatures commanded to be happy in their spheres at least by implication if not by word? What a dreary world this would be should all life be removed. What is more joyful to the ear than the voice of the robin on an early spring morning as he sings his song? The voice of the thrush, the meadow lark, even the bark of a friendly dog, each of them expressing their joy for their existence.

No! Man should be more the friend and never an enemy to any living creature. The Lord placed them here. [43]

President Smith recognizes that at times it is needful to kill animals for food and if 
they become a plague to mankind. However, after quoting extensively from Joseph Smith, Ir. and Joseph F. Smith, he concludes his plea for kindness with: "Is it not an excellent time for man to set the example as the Prophet has said." [44]

President Spencer W. Kimball has spoken in General Conference advocating kindness to animals and birds on three occasions: October, 1976, April, 1978, and October, 1978. The current President, Ezra Taft Benson, when he was President of the Quorum of the Twelve Apostles, stated: "I have often felt that the Lord is further counseling us in this revelation (Doctrine and Covenants, Section 89) against indiscriminately killing animals, for He has said elsewhere in scripture 'Woe be unto man that shedieth blood or that wasteth flesh and hath no need' (Doctrine and Covenants $49: 21$ )."[45]

The Latter-Day Saints scriptures, especially the Doctrine and Covenants and the Inspired Version of the Bible, lay a firm foundation for the practice of zoophily in the Church of Jesus Christ of Latter-Day Saints, and they stand alone as a Christian church with a doctrinal base and historical. activity advocating concern for animals.

\section{Notes}

1. Henry Stephens Salt, The Creed of Kinship (New York: E. P. Dutton \& Co.. 1935), pp. 1-2, 55-7.

2. Ibid., pp. 47-53. See Philip P. Hallie, The Paradox of Cruelty (Middletown, Conn.: Wesleyan University Press, 1969), Thomas Aquinas, Summa Theologica (Chicago: Encyclopedia Britannica Great Books, 1952), Book I, pp. 592-10, and Martin Luther, Luther's Works (St. Louis: Concordia Publishing House, 1960), Vol. IX, P. 220.

3. Marion E. Coville, An Appeal Against Slaughter (Syracuse: C. W. Bardeen Publishers, 1914). Also, Geoffrey L. Rudd, Why Kill for Food (Wilmslow, Cheshire: The Vegetarian Society, 1956), Howard Williams, The Ethics of Diet (London: F. Pitman, 1883), F.J. Simmons, Eat Not This Flesh: Food Avoidances in the old World (Madison: University of Wisconsin Press, 1961), and Joseph Ritson, An Essay on Abstinence from Animal Food as Moral Duty (London: R. Phillips, 1802).
4. Noah J. Cohen, Tsa'ar Ba'ale Hayim-The Prevention of Cruelty to Animals: Its Bases, Development and Legislation in Hebrew Literature (Washington, D.C.: The Catholic University of America Press, 1949). Also, see E. D. Buckner, The inmortality of Animals and the Relation of Man as Guardian (Philadelphia: George W. Jacobs and Co., 1903), Agnes Carr, The Animals and Birds Redeemed from Death: Their Eternal Glory (San Francisco: n.n., 1953), and Dix Harwood, Love for Animals (New York: n.n., 1928), pp. 14560.

5. "Empathetic Fallacy," unsigned editorial in America CI (August 1, 1959), p. 567. And Philip Austin, Our Duty to Animals (London: n.n.., 1885).

6. George Channing, "What Is a Christian Scientist?" Religions in America, ed. Leo Rosten (New York: Simon and Schuster, 1963), pp. 39-45.

7. Mary Baker Eddy, Unity of Good (Boston: Trustees under the Will of Mary Baker G. Eddy, 1919), p. 38 .

8. Mary Baker Eddy, Miscellaneous Writings (Boston: Trustees under the Will of Mary Baker G. Eddy, 1896), p. 36.

9. Ibid.. p. 223.

10. Ibid.. pp. 221-2.

11. Mary Baker Eddy, Science and Health with Key to the Scriptures (Boston: Trustees under the Will of Mary Baker G. Eddy, 1875), p. 514.

12. Ibid.

13. Mary Baker Eddy, Unity, p. 38, and Science, pp. 309, 311, 557.

14. Gerald Carson, Cornflake Cnusade (New York: Rinehart and Co., 1957), pp. 71146.

15. Joseph Bates, The Autobiography of Elder Joseph Bates (Battle Creek, Mich.: Seventh-Day Adventist Publishing Association, 1868).

16. Harold M. Walton, Medical Papers (Mountain View, Calif: Pacific Press Publishing Association, 1931), p. 94. 
17. Ellen G. White, Counsel on Diet and Foods (Washington, D.C.: Review and Herald Publishing Association, n.d.), pp. 81, 373.

18. Ellen G. White, Ministry of Healing (Washington, D.C.: Review and Herald Publishing Association, n.d.), p. 317. Also, see White, Counsel, p. 380.

19. Ibid., p. 315.

20. Ellen G. White, Patriarchs and Prophets (Washington, D.C.: Review and Herald Publishing Association, 1958), pp. 468-9.

21. questions on Doctrine (Washington, D.C.: Review and Herald Publishing Association, 1957), pp. 622-4.

22. George H. Westbeau, Little Tyke (Mountain View, Calif.: Pacific Press Publishing Co., 1956).

23. The Doctrine and Covenants of the Church of Jesus Christ of Latter-Day Saints (Salt Lake City: The Church of Jesus Christ of Latter-Day Saints, 1981), Section 49, verses $18-9,21$.

24. Joseph Smith, History of the Church of Jesus Christ of Latter-Day Saints, $2 \mathrm{~d} \mathrm{ed}$, rev, ed. B. H. Roberts (Salt Lake City: Deseret News, 1960), Vol. 2, pp. 71-2.

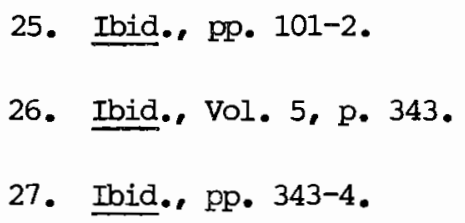

28. The Joumal of Discourses (Liverpool: F. D. Richards et. al., 1854-86), Vol 1. p. 203.

29. Ibid., Vol 11, p. 141.

30. James G. Lawrence, Instructor IIIC (Salt lake City: Deseret Sunday School Union Board of The Church of Jesus Christ of Latter-Day Saints, May 1962), pp. 154-5.

31. Lowell Bennion, Instructor XC (May, 1960), pp. 164-5.

32. Lowell I. Jackson, Instructor IVC (May, 1964), pp. 179-81.

33. The Children's Friend LI (Salt Lake City: The Primary Association of The Church of Jesus Christ of Latter-Day Saints, January, 1952), p. 22 .

34. Thomas C. Romney, The Life of Lorenzo snow (Salt Lake City: Deseret Book Co., 1955), pp. $34=5$

35. The Church of Jesus Christ of Latter-Day Saints, Conference Report (April, 1937), p. 15.

36. Herbert Murray Stewart, "A Normal Day in the Home of George Albert Smith," Improvement Era LIII (Salt Lake City, April, 1950), p. 287 .

37. Juvenile Instructor XIVIII (Salt Lake City: Deseret Sunday School Union Board of The Church of Jesus Christ of Latter-Day Saints, May, 1913), p. 309.

38. Ibid., IIII (April, 1918), pp. 1823. LXII (April, 1927), pp. 190-1. See also "The Origin of Man," Improvenent Era XIII (November, 1901), p. 81.

39. Conference Report (October, 1951), p. 180 .

40. Conference Report (April, 1952), p. 2.

41. Joseph Fielding Smith, The Signs of the Times (Salt lake City: Deseret Book Co., 1964), p. 39.

42. Joseph Fielding Snith, Church History and Modern Revelation (n.p., Council of Twelve Apostles of the Church of Jesus Christ of Latter-Day Saints, 1947), p. 193.

43. Joseph Fielding Smith, Answers to Gospel questions IV (Salt Lake City: Deseret Book Co.. 1963), pp. 43-4.

44. Ibid.

45. Conference Report (April, 1983), p. 71.

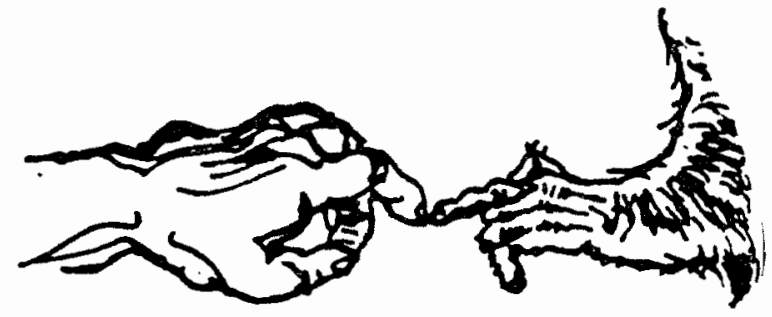

BETWEEN THE SPECIES 